\title{
Unpacking the Childcare and Education Policy Response to the COVID-19 Pandemic: Insights from the Canadian Province of Quebec
}

\author{
Sophie Mathieu
}

Sophie Mathieu is a postdoctoral fellow at the Université Teluq. She holds a PhD in sociology and has published in French and in English on childcare, parental benefits, and family policies in Quebec. Email: sophiemathieu@hotmail.com

Building from Blum and Dobrotićs conceptual framework, this paper shows that the decisions to reopen childcare centres and schools in the Canadian province of Quebec in 2020 were influenced by four goals: (1) protecting public health, (2) promoting academic success / fostering early education, (3) addressing social inequalities, and (4) helping parents to reconcile employment and care activities. Although the first three objectives were considered in the sequence of reopening, the government quickly chose to prioritize work-family reconciliation of reopening childcare centres and schools is not simply a consequence of evolving research showing lower risks associated with COVID-19 for young children, it also reflects the province's cultural norms toward mothers' employment and the high legitimacy of the state in subsidizing childcare.

Key words: pandemic; childcare; work-family reconciliation; Quebec above other objectives. Quebec's tight sequence

The first wave of the COVID-19 pandemic led to the closing of schools, childcare centres, and nonessential workplaces around the world, a unique situation that had important consequences on gender inequality (Carli, 2020; OECD, 2020). As parents with young children were required to work from home, mothers more than fathers adjusted (Yerkes et al., 2020) or reduced (Collins et al., 2020) their working hours to perform caregiving activities, including homeschooling (Zossou, 2021). Following the initial shock of the outbreak of the pandemic and the closing of the economy, governments faced dilemmas between different objectives, such as the need to protect public health and work-family balance, in their plan to reopen schools and childcare centres. This paper offers insights into these dilemmas in the Canadian province of Quebec through an account of the government's childcare and education policy responses during the first two waves of the pandemic. More specifically, I document the circumstances of the different phases of the reopening of childcare centres and schools between March and December 2020.

In a range of policy domains, including childcare, Canada's provincial governments choose their own and sometimes different paths (Friendly, Ballantyne \& Anderson, 2020; Prentice, 2020). While much has been written on the success (Jenson, 2002; Fortin et al., 2013) and challenges (Japel et al., 2008; Turgeon, 2014) of the "Quebec model" of childcare, very little research has been done to document the province's childcare response to the pandemic. This is an important gap to fill. Quebec is the Canadian province with the highest percentage of children aged 0 to 5 attending regulated childcare (Friendly, Ballantyne, \& Anderson, 2020), thanks to the province's well-established network of subsidized and low-cost childcare. Consequently, Quebec has the greatest workforce participation of mothers with children aged 0 to 5 and 6 to 15 (Friendly et al., 2020). Quebec also stands out as one of the provinces ${ }^{1}$ with the highest proportion of childcare centres that remained open in the early weeks of the pandemic-60\% of them in late April $2020^{2}-$ while that was the case for only $28 \%$ of childcare facilities in Canada (Friendly, Feltham, et al., 2020). Finally, the importance of learning from the Quebec experience has recently been reinforced by finance minister Chrystia Freeland, who stated, "Just as Saskatchewan once showed Canada the way on health care and British Columbia 
showed Canada the way on pricing pollution, Quebec can show us the way on childcare" (Government of Canada, 2020). For all of these reasons, one contribution of this paper moving forward with upcoming waves or other pandemics is to offer insights on what can be learned from Quebec's childcare policy response to the COVID-19 pandemic.

The paper is organized as follows. I begin by introducing Quebec's pre-pandemic childcare system for preschool and school-aged children. In line with the social investment paradigm, one objective that led to the implementation of a childcare network in the late 1990s was the development of the full potential of children. However, the other objective, helping parents to balance earning and caring activities, has received more political attention, because the network has been unable to meet the demand, due its popularity and the lack of space to accommodate every child. In the second section, I build from Blum and Dobrotićs (2020) conceptual framework to examine four policy goals for reopening childcare centres and schools, as parents, especially those with elementary school children, rely on schools to provide care while they work (Friendly, Ballantyne, \& Anderson, 2020). These goals are (1) protecting public health, (2) promoting academic success / fostering early education, (3) addressing social inequalities, and (4) helping parents to reconcile employment and care activities. Quebec's childcare and education policy response is documented in the third section. Although the Quebec government did not openly emphasize one objective at the expense of another, the protection of public health was prioritized for a very short period of time, when the number of people infected with COVID-19 was relatively low. As the childcare policy-response to the pandemic evolved, the government had to make decisions about who would access childcare services, at what cost, and under what conditions. Similar decisions had to be made with the reopening of schools, and Quebec had to prioritize which students - the youngest, the oldest, the most vulnerable, or those in transition years-would have access to the classroom for in-person schooling. These decisions reflect the dominance of the issue of work-family balance above the three other policy goals. This dominance is made obvious by Quebec's decision to reopen childcare centres and schools more rapidly than most other provinces, despite having the worst epidemiologic situation in Canada. In the conclusion, I discuss some the lessons of Quebec's childcare policy response as it relates to Quebec's pre-pandemic approach to childcare.

\section{Subsidized and low-cost childcare at the heart of Quebec's family policy}

Quebec is known both by national and international standards as the province that most closely mirrors the egalitarian model of the Nordic countries, and it has even been referred to as a "paradise for families" (Godbout \& St-Cerny, 2008). Quebec has been successful at reducing gender inequalities as it has managed to support the combination of paid work and family responsibilities. For example, Quebec is the province that offers the most accessible and the most highly compensated parental leave, including "take-it-or-lose-it" paternity benefits, through Quebec's Parental Insurance Plan (Mathieu et al., 2020).

At the heart of Quebec's family policy is its childcare network of subsidized and low-cost childcare. While a thorough discussion of the social and policy context that led to the implementation of Quebec's family policy is beyond the scope of this paper, it is worth highlighting that the introduction of the provincial childcare network signalled a sharp turn toward social economy (Arsenault, 2018). As in other provinces, Quebec's social economy policies were influenced by a business-case frame (Prentice, 2009) and social investment ideas (Jenson \& St-Martin, 2003) under which childcare is designed as an investment with exceptional payoffs. In the words of then-premier Lucien Bouchard in 1997:

Our primary motivation meets a simple and unavoidable requirement: the development of children and equal opportunities. As the very title of the document eloquently states [Children at the Heart of Our Choices], we firmly place children at the heart of our choices.... We are making this collective investment 
primarily for children, to ensure they have the best chance of success. The benefits to children of early stimulation programs are widely demonstrated.... It has also been shown that such programs have a particularly positive effect on children from disadvantaged backgrounds. Early intervention reduces the risks associated with learning and behavioural problems and reduces the chances of dropping out. (Archives politiques du Québec, 1997, translated by the author) ${ }^{3}$

Explaining the implementation of childcare as a shift from a "citizenship regime" to a "social investment state" (Jenson \& St-Martin, 2003), however, does not mean children have had access to high-quality childcare. In their analysis of 1,574 childcare centres between 2000 and 2003, Japel et al. (2008) showed that only $27 \%$ of them offered "good," "very good," or "excellent" quality of care, an observation that has not significantly changed in recent years (Observatoire des tout-petits, 2018).

Quebec's network of childcare is complex and the quality of care varies significantly between nonprofit and forprofit centres. Table 1 shows the different types of licensed childcare in Quebec as of March 2020. The "centres de la petite enfance" (CPE) are the cornerstone of Quebec's family policy; they are nonprofit and reduced contribution childcare facilities that can accommodate up to 80 children. Although the CPEs provide the highest quality of care (Japel et al., 2008; Japel \& Friendly, 2018), they offer less than one-third (31.6\%) of all childcare spaces.

Table 1. Licensed Childcare in Quebec, March 2020

\begin{tabular}{|l|l|l|}
\hline & Number of spaces & Proportion \\
\hline Noncommercial services & & \\
Centres de la petite enfance (CPE) & 96703 & $31.6 \%$ \\
\hline Commercial services & & \\
Subsidized centres & 47424 & $15.5 \%$ \\
Nonsubsidized centres & 70421 & $23.0 \%$ \\
\hline Childcare in family environment & 91604 & $29.9 \%$ \\
\hline TOTAL & $\mathbf{3 0 6} \mathbf{1 5 2}$ & \\
\hline
\end{tabular}

Source: Famille Québec (2020a)

Commercial childcare services come in two forms. Subsidized commercial centres, known as garderies (15.5\% of all childcare spaces), offer services at the same cost as the CPEs. Childcare costs are low in Quebec; in 2021, a subsidized space for one child (whether in a commercial childcare centre or in a CPE) cost $\$ 8.50$ per day, including 10 hours of care, two snacks, and one lunch. There are also nonsubsidized commercial childcare centres $(23 \%$ of childcare spaces) where parents pay the full fee for childcare and where the quality of services is the lowest (Japel et al., 2008), notably due to a low proportion of trained staff (Ministère de la famille, 2020). In Montreal, a nonsubsidized childcare space can cost up to $\$ 80$ per day (Schué, 2019), but parents are entitled to a tax credit for a portion of that amount. Finally, both subsidized and nonsubsidized licensed childcare spaces are offered in "family environments." Childcare in family environments is typically of better quality than in the commercial garderies yet of lower quality than services provided in CPEs (Japel et al., 2008).

Inconsistent with the objectives of developing the full potential of children and addressing social inequalities is the fact that vulnerable children-those who arguably need the most "investment"-are underrepresented in childcare centres, let alone in facilities that offer the highest quality of care, the CPEs. In 2018, the median family 
income of families with a child aged 5 and under was $\$ 82,000$ in Quebec, but $\$ 98,000$ for families with a child in a CPE (Ministère de la famille, 2020, p. 18). In Parc-Extension, St-Michel, and Montreal-Nord, low-income neighbourhoods in Montreal where the median family income for families with a child aged 5 and under is $\$ 38,000$, one childcare space out of seven is provided by a CPE. In addition, children with special needs such as autism have a lower placement rate (73\%) than children without special needs (83\%; Ministère de la famille, 2020, p. 12).

Access to a childcare centre, more than its quality, has been a political issue since the early 2000s, mainly because the network has been very popular and unable to meet the demand. Parental pressure to open new childcare spaces rapidly and tax incentives to use for-profit centres paved the way for a rapid increase in lower-quality commercial childcare centres since 2003 (Mathieu, 2019). Yet, many parents in need of childcare are confused by the differences between CPEs and subsidized garderies because they are both licensed and regulated and because they offer services at the same cost (Mathieu, 2019). Recently, the social movement "Ma place au travail," created by women unable to return to work after their maternity leave due to the lack of childcare, has pressured the government to create new spaces rapidly, setting aside the issue of quality. As a way to fulfill its promise to create more spaces, the government has recently relaxed the hiring criteria for childcare workers, a point further discussed below.

In addition to its network of preschool childcare services, Quebec offers before- and after-school services. Elementary schools typically provide childcare services between 7:00 a.m. and the beginning of class time, after school until 6:00 p.m., and during lunchtime. Parents who do not wish to send their child to before- and/or afterschool care can choose to pay only for lunchtime childcare services at a daily cost of \$1.76 per child (in 2020).

Both childcare for preschool children and before- and after-school programs are offered roughly at the same cost and are very popular. In 2019, 64\% of preschool children were cared for in a CPE or a garderie (Ministère de la famille, 2019), and 59\% of children attending a public elementary school (between kindergarten and grade 6) attended before- and/or after-school childcare (Conseil supérieur de l'éducation, 2020). The two programs are administered by different ministries: the Ministry of Families for preschool childcare and the Ministry of Education for beforeand after-school childcare. Another key difference is that while waiting lists to access preschool childcare are long, access to before- and after-school programs is universal, because services are provided by the schools.

Before- and after-school childcare was not officially part of Quebec's 1997 family policy but has nonetheless been closely associated with it (Tougas, 2002). Despite differences between the provision of preschool and before- and after-school childcare, I examine the sequence of reopening of childcare for preschool and school-aged children in tandem rather than separately. This means that I also examine governmental decisions regarding the reopening of schools. As Friendly et al. (2020) note, the pandemic highlighted the fact that parents with school-age children depended on schools for childcare as much as for education. Furthermore, some of the objectives (like facilitating work-family reconciliation) and decisions (such as having older children pursue their education remotely) in the sequence of reopening childcare and schools were intertwined and cannot be examined separately.

\section{Building from Blum and Dobrotić's conceptual framework}

In their paper "Childcare-Policy Responses in the COVID-19 Pandemic: Unpacking Cross-Country Variations," Blum and Dobrotić (2020) develop a conceptual framework to explain cross-country differences in pandemic childcare-policy responses. Drawing on public health research, they identify two ideal prevention strategies: the population approach, which has a stronger prevention potential than the second strategy because it addresses the whole population, and the high-risk approach, which targets individuals and avoids generalized intervention. Beyond the decision to keep childcare centres and elementary schools open (as in Sweden) or closed (as in Italy), the types and timing of childcare-policy responses to the pandemic have varied widely. In the words of Blum and 
Dobrotić,

many countries exhibit hybrid approaches, varying not only from more lenient to strict, but also from universal to selective closures/re-openings, i.e. allowing certain groups to keep access or re-enter earlier. In such an uncertain situation, countries' approaches may be affected by factors that go beyond public-health concerns (e.g. specific regime paths, government constellations) and have different implications for the groups targeted (or not) and therefore gender and social inequalities. (p. S546)

As countries move through a sequence of partial reopenings, different childcare and education priorities shed light on who gains early access to services, when, and under what conditions. In accordance with, and building from, Blum and Dobrotićs argument, I identify four nonmutually exclusive goals that guided the reopening of childcare centres and schools in Quebec (Table 1): (1) protecting public health, (2) promoting academic success / fostering early education, (3) addressing social inequalities, and (4) helping parents to reconcile employment and care activities.

Each of these goals has theoretical and practical implications. For instance, if the objective is to protect public health and to apply physical distancing rules, getting older children and young adults, who can more easily follow health recommendations, back into the classrooms will be prioritized over in-person schooling for younger children, who may have difficulties following physical distancing rules. The first objective, protecting public health, is the closest to the population approach, and it is the only objective that was not an explicit part of Quebec's family policy prior to the pandemic.

At the other end of the spectrum is the fourth objective of helping parents reconcile paid and family responsibilities. Following this goal, younger children, who are more likely to struggle with independent online learning, will be given priority access to in-person schooling, not only because older children and young adults can more easily pursue online education with minimal supervision, but also because younger children require more supervision and need to be cared for while their parents work. The objective of helping parents balance earning and caring responsibilities, as we have seen above, is a key component of Quebec's family policy, though the second and third objectives, promoting academic success / fostering early education and addressing social inequalities are also in tune with the "social investment" paradigm, and the official government discourse in Quebec. 
Table 2. Government Objectives For Reopening Childcare Services and Schools and Theoretical and Practical Implications of These Decisions

\begin{tabular}{|c|c|c|}
\hline Objective & Theoretical implications & Practical implications \\
\hline $\begin{array}{l}\text { 1.Protecting public } \\
\text { health. }\end{array}$ & $\begin{array}{l}\text { Applying rules set by Public } \\
\text { Health (physical distancing } \\
\text { and the use of face coverings). }\end{array}$ & $\begin{array}{l}\text { - Giving priority access to older children who can follow phys- } \\
\text { ical distancing rules. } \\
\text { - Allowing children with health conditions (or living with par- } \\
\text { ents and/or grandparents with health conditions) not to attend } \\
\text { school in person. } \\
\text { - Decreasing the number of students in the classroom to reduce } \\
\text { risks of transmission. } \\
\text { - Adding more ventilation to classrooms. } \\
\text { - Modifying school hours to limit contact among students of } \\
\text { different ages. } \\
\text { - Strictly enforcing social distancing rules. }\end{array}$ \\
\hline $\begin{array}{l}\text { 2.Promoting aca- } \\
\text { demic success / } \\
\text { fostering early } \\
\text { education. }\end{array}$ & $\begin{array}{l}\text { Prioritizing children in tran- } \\
\text { sition years and children with } \\
\text { learning difficulties and/or } \\
\text { with special needs. }\end{array}$ & $\begin{array}{l}\text { - Giving priority access to children in the first and last years of } \\
\text { elementary and secondary. } \\
\text { - Giving priority access to students enrolled in their first se- } \\
\text { mester of CEGEP or university. } \\
\text { - Giving priority access to children with learning difficulties. } \\
\text { - Giving priority access to children with special needs (such as } \\
\text { autism) who are in childcare. }\end{array}$ \\
\hline $\begin{array}{l}\text { 3.Addressing social } \\
\text { inequalities. }\end{array}$ & Reducing class inequalities. & $\begin{array}{l}\text { - Giving priority access to "disadvantaged" children (e.g., } \\
\text { families who receive social assistance payments, immigrant } \\
\text { families, etc.). } \\
\text { - Offering computers and tablets to facilitate remote learning } \\
\text { during temporary lockdowns. }\end{array}$ \\
\hline $\begin{array}{l}\text { 4. Helping parents } \\
\text { to reconcile em- } \\
\text { ployment and care } \\
\text { activities. }\end{array}$ & $\begin{array}{l}\text { Reducing work-family con- } \\
\text { flict, especially for single par- } \\
\text { ents, dual-earner families, and } \\
\text { families with young children } \\
\text { or children with special needs. }\end{array}$ & $\begin{array}{l}\text { - Giving priority access to younger children (in childcare cen- } \\
\text { tres and in early years of schooling). } \\
\text { - Giving priority access to children whose parents fit certain } \\
\text { predetermined criteria (e.g., single parents and dual-earner } \\
\text { families). }\end{array}$ \\
\hline
\end{tabular}

Source: Adapted from Blum and Dobrotić (2020).

As research on COVID-19 evolved, so too did the practical implications of each objective. For instance, although teenagers and young adults appear to adhere more easily to physical distancing rules than young children, it has also been argued that young children are less contagious, which makes childcare facilities less dangerous to reopen (Boast et al., 2020) than workplaces and schools, where teenagers and young adults are more likely to disregard social distancing rules and gather in large groups. Thus, strategies to protect the public's health adapted as the heath crisis continued to unfold. As we will see below, although they were not addressed equally, none of the Quebec government's four ideal objectives was openly prioritized to the detriment of another. The objective 
of helping parents to reconcile employment and care activities, however, emerged quickly and clearly in Quebec, despite an increasing number of people infected with COVID-19.

\section{Quebec's childcare and education policy response to the pandemic}

In the first days of the COVID-19 crisis, public health concerns across Canada, including Quebec, led provincial governments to adopt strong childcare-policy responses. Under the population approach, strict containment policies resulted in universal childcare closures, with emergency childcare provided for key workers (Blum \& Dobrotić, 2020). On March 13, 2020, the government of Quebec announced that schools and childcare centres would close for 14 days. The government also announced the following Monday that subsidized childcare centres, both CPEs and garderies, as well as emergency school childcare services, were to remain open for children of healthcare and essential services workers.

Unlike in other countries (such as Austria and Belgium), where childcare centres remained operational for children of both key workers and of working parents without other care options (Blum \& Dobrotić, 2020), the provincial government made it clear that in Quebec, childcare services were only to be used by a limited group of essential workers without other childcare options. To some extent, Quebec's approach was more restrictive than the path chosen by some of the other provinces. In early May, 95\% of open childcare centres were restricted to children of essential workers in Quebec, a proportion well above the Canadian average (73.8\%) and in sharp contrast with Saskatchewan, where this was the case for only $35 \%$ of open centres (CRRU, 2020).

Parents in Quebec were encouraged not to use emergency childcare and had to show proof of their employment in an essential service. The Minister of Families, Mathieu Lacombe, even posted a video on social media asking two-parent families with only one parent classed as an essential worker to keep their children home and rely on a friend or older child to help with childcare. The social acceptability of relying on emergency childcare services quickly dwindled as this option was framed as a last resort. Between March 16 and March 20, 2020, 6,200 children attended emergency childcare daily. That number dropped to 5,200 the following week, meaning that only $1.7 \%$ of preschool children were being cared for in an emergency centre (Famille Québec, 2020b).

Emergency childcare for preschool children was offered exclusively in subsidized facilities and, for kids aged 5 to 12, in 400 designated elementary schools. Subsidized home childcare providers affiliated with a CPE were given the choice to either offer emergency childcare or close. Nonsubsidized commercial childcare spaces, whether in facilities or in family environments, were not given that option and were told they had to close by April 3. This meant that parents whose children were cared for in nonsubsidized garderies and who needed emergency childcare had to relocate their children to a new childcare facility (Dion-Viens, 2020). Emergency childcare for both preschool and school-aged children was offered Monday to Friday, from 7 a.m. to 6 p.m., as was the case before the pandemic.

Quebec's universal population approach translated not only into the decision to impose a general lockdown, but also into the decision to universally eliminate childcare costs while emergency childcare services were being offered. Quebec was not the only province to waive childcare fees to essential workers: four other jurisdictions, Newfoundland and Labrador, Prince Edward Island, Ontario, and Yukon also offered free childcare for frontline workers. In contrast, almost all essential workers were asked to pay their full childcare fees in New Brunswick, Manitoba, and Saskatchewan (Friendly, Forer, et al., 2020). In Quebec, however, the decision was made not to impose fees to anybody from the start, meaning that neither parents who used emergency childcare services nor those who kept their children home but who wanted to keep their space were charged childcare fees. While most other provinces eventually did not permit centres to charge parent fees for closed services to hold their place, in 
New Brunswick childcare fees were permitted if staff were not laid off.

Emergency childcare operated under strict new rules. For instance, ratios were revised and CPEs operated at $30 \%$ capacity (from 80 children down to 24), with each éducatrice (educator / childcare provider) having no more than $50 \%$ of the normal number of children in a group. Emergency childcare ratios for school-aged children were reduced from 20 children per educator to 10. Parents were not allowed to circulate in the childcare facility; a designated staff member was responsible for welcoming and leading children into the childcare centre and returning them to their parents at the end of the day (Association québécoise des CPE, 2020a).

These new rules reflected the dominance of public-health concerns over other issues, such as work-family balance-given the restricted access. In the CPEs, toys that could not be easily washed (e.g., plush toys, costumes, blankets) were removed; childcare workers were also instructed to avoid activities that necessitated physical contact among children, such as holding hands. Although educators were not encouraged to wear face masks or gloves (Association québécoise des CPE, 2020a), this directive changed rapidly (Association québécoise des CPE, 2020b). Childhood educators and home childcare providers were quickly required (in early May 2020) to wear a visor or goggles and a procedural face mask at almost all times (and that is still the case now, at the time of writing). This requirement has led health specialists to argue that language development for young children may be impaired and that communication and interactions with children are more difficult (Cloutier, 2020), especially for children with special needs, such as autism.

\section{Moving towards a hybrid approach}

Although childcare centre closures happened simultaneously across the province, the progressive return to "normal" was conducted in different phases, spread over several weeks. As Blum and Dobrotić (2020) explain, "under the re-openings, the variety of childcare-policy responses increased, as these have developed into more long-term strategies" (p. S552). Although Quebec's reopening model was a "hybrid" approach, falling midway between the "general" approach used in the first week of the pandemic and the "high-risk" approach implemented in the fall, the province moved forward with reopenings at a faster pace than in the other provinces, though the epidemiologic situation was the worst in the country. For example, on May 1, Quebec reported 1100 new positive tests for a population of 8.6 million; this represented 67\% of all new cases in Canada (1635) for that day. Meanwhile, Ontario, with a population of 14.7 million, reported 620 new cases.

Quebec nonetheless went ahead with the reopening plan it had announced on April 27. That plan consisted of a sequence of targeted reopenings that began on May 11, making Quebec one of the three provinces to reopen childcare facilities the earliest (with Newfoundland and Labrador and Alberta). ${ }^{4}$ In phase 1, in mid-May, childcare centres welcomed back between $30 \%$ and $50 \%$ of their children. In phase 2, that proportion rose to $50 \%$, and it reached $75 \%$ in phase 3 . All children were given the option to return to their childcare facility in the fourth phase of reopening, on June 22 (Table 3 ). 
Table 3. Original Multiphase Reopening Plan for Childcare Services in Quebec, Spring 2020

\begin{tabular}{|c|c|c|c|c|}
\hline \multirow{3}{*}{$\begin{array}{c}\text { Phase number and } \\
\text { date }\end{array}$} & \multicolumn{4}{|c|}{ Childcare facilities } \\
\hline & \multicolumn{2}{|c|}{$\begin{array}{l}\text { Quebec (except Montreal metropolitan } \\
\text { community) }\end{array}$} & \multicolumn{2}{|c|}{ Montreal metropolitan community } \\
\hline & Capacity & $\begin{array}{l}\text { Children per educator } \\
\text { ratios* }\end{array}$ & Capacity & $\begin{array}{l}\text { Children per educator } \\
\text { ratios* }\end{array}$ \\
\hline Phase 1 & & & Emergen & are services \\
\hline $\begin{array}{l}\text { May } 11 \\
\text { May } 19\end{array}$ & $30-50 \%$ & $2-4-5$ & $30 \%$ & $2-4-5$ \\
\hline $\begin{array}{l}\text { Phase } 2 \\
\text { May } 25\end{array}$ & $50 \%$ & $2-4-5$ & $50 \%$ & $2-4-5$ \\
\hline $\begin{array}{l}\text { Phase } 3 \\
\text { June } 8\end{array}$ & $75 \%$ & $3-6-8$ & $75 \%$ & $3-6-8$ \\
\hline $\begin{array}{l}\text { Phase } 4 \\
\text { June } 22\end{array}$ & $100 \%$ & $5-8-10$ & $100 \%$ & $5-8-10$ \\
\hline
\end{tabular}

*Educator ratios represent three categories of infants/toddlers: under 18 months, 18 months to under 48 months, over 48 months.

Source: Famille Québec (2020b)

A similar strategy was developed by the government for reopening schools (Table 4), as the objective of helping parents reconcile earning and caring responsibilities emerged as a top priority in the spring. Again, despite having the highest number and proportion of cases in Canada, Quebec became the first province to reopen elementary schools (except in the Montreal metropolitan community, where the number of cases was too high; Table 4), closely followed by Manitoba and British Columbia (Friendly, Forer, et al., 2020). Other provinces chose to keep schools closed until September 2021. In line with the objective of helping parents to balance earning and caring responsibilities, but in contrast with the goals of promoting academic success and addressing social inequalities, all students enrolled in secondary and postsecondary education had to pursue their education remotely.

Table 4. Reopening Plan for Elementary and Secondary Schools, CEGEPs, and Universities in Quebec, Spring 2020

\begin{tabular}{|l|l|l|l|l|l|}
\hline & \multicolumn{2}{|l|}{ Elementary schools } & $\begin{array}{l}\text { Secondary } \\
\text { schools }\end{array}$ & CEGEP & Universities \\
\hline & $\begin{array}{l}\text { Quebec (except Montreal } \\
\text { metropolitan community) }\end{array}$ & $\begin{array}{l}\text { Montreal metropolitan } \\
\text { community }\end{array}$ & \multicolumn{2}{|l|}{ Across the province } \\
\hline Date of & May 11 & $\begin{array}{l}\text { Originally set to open } \\
\text { May 19. Postponed to } \\
\text { September 2020. }\end{array}$ & Sep 2020. & $\begin{array}{l}\text { Sep 2020. } \\
\text { Most courses } \\
\text { are online. }\end{array}$ & $\begin{array}{l}\text { Sep 2020. Most } \\
\text { courses are online. }\end{array}$ \\
\hline
\end{tabular}

Quebec's decision to prioritize a return to normal activities for children under 12 as soon as May is not surprising. As discussed above, since the late 1990s, work and family reconciliation has been at the heart of the province's family policy. Supporting parental employment (Jenson, 2002), especially mothers' employment (Fortin et al., 2013) has risen above other family policy priorities, such as fostering children's development, despite the official government discourse of the need to invest in the development of children's full potential. To help nonsubsidized 
childcare centres resume service during the progressive reopening period, and despite the lower quality of care in these centres, the government provided them with $\$ 22$ million in financial support. That meant that commercial childcare centres received $\$ 10.10$ per spot once childcare centres reopened to help make up income lost due to reduced educator-child ratios. The government of Quebec had already paid $\$ 30.5$ million to nonsubsidized childcare centres to cover part of their fixed costs in mid-May to avoid major financial hardship.

The other three objectives-protecting public health, promoting academic success / fostering early education, and addressing social inequalities - did not completely disappear from the government's agenda, but they were lower in priority. For instance, in line with the goal of protecting public health, parents who kept their preschool child home had the option of maintaining that child's childcare space until September (provided they paid the usual fee for care at their facility). In addition, in-person attendance was not mandatory for elementary school children.

With regards to the objectives of promoting academic success / fostering early education and reducing social inequalities, childcare facilities were permitted to accept up to $50 \%$ of the children registered under their permit during the first phase of reopening. This measure was intended to ensure childcare for vulnerable children or children with special needs, who were given priority during reintegration. In sharp contradiction with this objective, however, the quality of services was compromised by a ministerial order in May, when the government relaxed the hiring rules for childcare workers as a strategy to overcome a labour shortage and maintain services. Since then, only one out of three educators must have a college diploma to work in a childcare centre, compared to two out of three workers previously.

In elementary schools, attendance remained on a voluntary basis at the time of reopening, even for children with learning difficulties or in their last year of elementary school. For vulnerable school-age children, the government launched "pedagogical camps" in early June, which required a partial reopening of some school buildings. School boards determined which students were eligible for the camps, where social distancing measures were implemented, and classes were kept small. Educational camps were made available for elementary and secondary students in the greater Montreal area and for secondary schools across the province; overall, around $70 \%$ of secondary schools offered pedagogical camps (Robillard, 2020). ${ }^{6}$ Again, though, and to some extent in contradiction with the objective of promoting academic success for vulnerable students, attendance was not mandatory for eligible students, and because they adhered to the academic calendar, the pedagogical camps were only offered for three weeks.

\section{A high-risk childcare policy response amid an increasing number of cases}

The government's first priority, helping parents reconcile earning and caring responsibilities, led the province to adopt a "high-risk" policy response to the pandemic as early as the end of June. Since then, all childcare establishments, including childcare provided in family settings and in nonsubsidized centres, have been allowed to deliver childcare services to the maximum number of children indicated on their permit, even in "hot" zones. High-risk strategies avoid generalized interventions in favour of targeting vulnerable groups in need of special preventive care and treatment. According to Blum and Dobrotić (2020), applying high-risk prevention approaches results in less stringent interventions, such as the rules regarding keeping a child at home if they exhibit mild symptoms. The government of Quebec chose this path even though the province still had the highest number of infections and deaths due to COVID-19 in Canada and despite warnings from the national public health director that if people were not careful, the first wave would pale in comparison to the impending second wave. ${ }^{7}$

This high-risk approach was made apparent in other initiatives early in the fall, when the government announced the implementation of a four-level colour-coded regional alert system (green, yellow, orange, and red, representing escalating levels of danger). The system aimed to keep the public informed about the current level of risk and help 
them understand the actions the government would take in case of a serious outbreak. For instance, "red zone" restrictions could prohibit certain nonessential activities in order to avoid a province-wide lockdown.

Although the transition from an orange to a red zone entailed new restrictions in elementary and secondary schools (e.g., the suspension of extracurricular activities), this same logic did not apply to childcare. Indeed, in its original version, Action Plan in the Event of a Second Wave, the Ministry of Families' (2020) plan stated: "Educational childcare services are an integral part of our social safety net because they promote the full development of young children and enable their parents to continue working" (p. 5) and, in accordance with these two objectives, that "no educational childcare services will be shut down except in the case of an outbreak in a facility" (p. 10, emphasis added). In other words, in the event of a targeted renewed lockdown aimed at a specific region or activity sector, the plan would still be to keep childcare services open. In such a case, attendance would be voluntary, but the regular childcare rate would be paid by parents regardless of whether their child used the service.

The government's high-risk approach was also reflected in the decision to have before- and after-school childcare services resume as normal, with regular fees and the same 20-to- 1 student to educator ratio. For schools located in red zones, childcare services were organized on the principle of stable class groups: Students remained within the same bubble during school hours, both indoors and outdoors. ${ }^{8}$ Accordingly, students were not permitted to play on school grounds upon arriving in the morning. Rather, they immediately entered their classroom to avoid contact with children outside their bubble and ate lunch and played after school with the same group of classmates. Children attending before- and after-school programs were not required to stay physically distanced from other children attending these programs.

The reopening of before- and after-school childcare went hand in hand with the decision to reopen elementary and secondary schools, while CEGEPs and universities remained closed. Unlike in Ontario and British Columbia, where parents were given the option of remote education for their children, in-person school attendance was made compulsory for all elementary and secondary students in the province, though schools became important sites of transmission. Only students with a serious health condition that made them more vulnerable to COVID19 were exempted from that rule. Classrooms, not schools, closed for a period of two weeks when a child tested positive for COVID-19. In Quebec, only students with a serious health condition that made them more vulnerable to COVID-19 were exempted from compulsory in-person attendance at school.

Schools hours in Quebec did not change, ${ }^{9}$ nor did the school calendar and student/teacher ratios. Students continued to be taught all subjects (including arts and physical education) without physical distance. Schools' pandemic safety protocols included mask wearing (for students in grades 5 and higher), limiting student contact by keeping children within a consistent bubble, opening classroom windows in schools with inadequate ventilation systems, and advising children to dress appropriately for colder classrooms and more outdoor time during the school day. Parents were also asked to keep their child home for a determined period of time in case of mild symptoms such as a runny nose.

Starting in early October and as the number of cases rose, a "blended" learning format was implemented for students in secondary 4 and 5 (the equivalent of grades 10 and 11 in other Canadian provinces). This approach, which combined in-person teaching and distance learning with in-person classes every other school day, was later extended to secondary 3 (grade 9) students. In addition, children attending schools in red zones were required to wear a face mask at all times while on school grounds.

Quebec's colour-coded regional alert system allowed the government to meet its objective of helping parents continue to work while also avoiding generalized interventions. A consequence of prioritizing employment goals 
was that academic success played second fiddle. For example, the needs of students in their last year of secondary school and in their first semester of CEGEP or university, who had already missed many weeks of class in the spring and who continued to face the challenge of adapting to changing, inconsistent, and insufficient educational formats and learning platforms, were not the top concern. Students with learning difficulties, special needs, or low motivation in secondary 4 and 5 only had limited access to in-school learning. Students' age and, in the case of CEGEP and university, the suitability of remote learning for specific subjects, became important variables in determining priority access to in-person learning.

\section{Discussion and conclusion}

Building from Blum and Dobrotićs (2020) conceptual framework, this paper has provided insights to unpack Quebec's childcare and education policy response to the COVID-19 health crisis, around four nonmutually exclusive goals. Three of these goals, protecting public health, promoting academic success / fostering early education, and addressing inequalities, were not highly prioritized in the sequenced phases of reopenings, though they were always given some consideration. For example, the reopening of elementary schools in Montreal was delayed due to the high number of people infected with COVID, vulnerable children were prioritized in the early phases of the reopening of childcare, and pedagogical camps for vulnerable students were implemented in June 2020 .

Somewhat paradoxically, however, as the number of daily COVID-19 cases reached new heights, with $75 \%$ of outbreaks occurring in workplaces and schools (Rivard, 2020), the government moved from a universal general approach toward a riskier targeted strategy. That new strategy reflected the government's decision to prioritize work-family reconciliation above other considerations. Accordingly, access to childcare and education services was offered for all children in an effort to enable as many parents as possible to continue to work full time.

What can we learn from Quebec's childcare and education policy response to the pandemic? That Quebec seems to have been more agile than the other provinces at responding to the need to close and reopen childcare services. This agility can be seen in the province's tight sequence of universal closure of services to all children (except for those of frontline workers), to reopening of elementary schools in mid-May and the full reopening of childcare centres in June 2020.

Quebec's childcare and education policy response was not simply a consequence of evolving research showing that childcare settings represented low risk for the transmission of COVID-19. As Linda White argues (2017), the primary mechanisms that lead to policy decisions are not purely rational and grounded in evidence-based arguments; they are also cultural. In Quebec, gender norms regarding mothers' labour market participation are persuasive and rooted in an institutional and policy context that has promoted a dual breadwinner/caregiver model. The legitimacy of that model was not challenged during the lockdown, though mothers reported having more difficulties than men in coping with their new caregiving constraints (Mathieu \& Tremblay, 2021). Similarly, the state has a legitimate role in subsidizing the provision of childcare in Quebec; thus the government did not face any opposition when extending financial assistance to nonsubsidized commercial centres, which, by definition, have not been publicly funded in the past. The alternative, the closing of many childcare centres due to bankruptcy, was not a viable political option.

Quebec's transition toward a high-risk approach was facilitated by the Quebecoises' highest employment rate in Canada among those aged 25-44 (83\%); in comparison, the employment rate of women in the same age group is 77\% in Ontario (Statistics Canada, 2020). Most importantly, Quebec was able to rely on a solid and well-established childcare network in which most childcare spots are being subsidized by the government. In 
other provinces, childcare subsidies have been low, mainly because Canada's historical liberal welfare state and trend toward maternal provision of childcare have translated into cash-for-care models that impede better care structures (Bezanson et al., 2020).

Universal access to low-cost subsidized childcare seems to have been the buffer against closure. While it was reported that as many as 837 childcare-in-family-environment services permanently closed between March and November 2020 (Samson, 2021), the provision of before- and after-school childcare services was not affected by the pandemic, because those services were provided in elementary schools, where each child is guaranteed a space.

By focusing on the instrumentality of childcare to help parents combine earning and caring responsibility, the mobilization of childcare in Quebec_-both before and since the beginning of the pandemic-has never really sidestepped the issue of gender equality and mothers' role as breadwinners. On the downside, because of the strong focus on the need to create and maintain childcare spaces, less attention has been given to the issue of quality of care to foster early education and address social inequality. The balance between offering childcare to a larger number of children-37,000 spaces are currently missing in the network (Ouellette-Vézina, 2021)—and providing quality educational services, especially for vulnerable children, could be the biggest challenge Quebec's childcare network has yet to overcome.

\section{Acknowledgments}

The author is grateful to the two anonymous reviewers for their careful reading of the paper and their insightful comments and suggestions.

\footnotetext{
${ }^{1}$ Yukon had a slightly higher percentage of their childcare centres opened (63\%).

${ }^{2}$ Data was collected between April 27 and May 1.

${ }^{3}$ The original text reads: Notre motivation première répond à une exigence simple et incontournable : le développement des enfants et l'égalité des chances. Comme l'indique de façon éloquente le titre même du document [Les enfants au cœur de nos choix], nous plaçons résolument les enfants au cœur de nos choix. [...] Cet investissement collectif, nous le faisons d'abord pour les enfants, pour leur assurer les meilleures chances de réussite. Les effets bénéfiques pour les enfants de programmes de stimulation précoce sont largement démontrés [...] II est également prouvé que de tels programmes ont un effet particulièrement positif pour les enfants des milieux défavorisés. Une intervention en bas âge diminue les risques liés aux problèmes d'apprentissage et de comportement, elle réduit les probabilités de décrochage.
}

${ }^{4}$ In British Columbia, child care centres were not mandated to close but many chose to close and some provided emergency care (CRRU, 2020).

${ }^{5}$ On May 14, 2020, Premier François Legault announced that the first phase of reopening was postponed to June 1 for the Montreal metropolitan area. Services were fully resumed on July 13, 2020.

${ }^{6}$ Some schools offering specialized educational services to disabled students reopened their doors as well.

${ }^{7}$ In the words of Dr. H. Arruda, "quand ça flambe dans une deuxième vague, la première vague, c'est de la petite bière par rapport à la deuxième" (Bossé, 2020).

${ }^{8}$ When this was not possible, (when two groups would be in the library or the gymnasium at the same time, for instance), physical distancing of 2-metres was used to separate the groups.

${ }^{9}$ Small adjustments were made to recess and lunch time schedules in schools to avoid crowding in common areas. 


\section{References}

Archives politiques du Québec. (1997). Présentation du livre blanc: Les enfants au cœur de nos choix. Allocution de Lucien Bouchard, 23 janvier 1997. https://www.aqcpe.com/affaires-publiques-et-gouvernementales/allocution-de-lucien-bouchard-23-janvier-1997/

Arsenault, G. (2018). Léconomie sociale au Québec: Une perspective politique. Presses de l'Université du Québec.

Association québécoise des CPE. (2020a, , March 22). Guide des bonnes pratiques pour l'organisation des services de garde éducatifs en CPE pendant la mesure d'urgence sanitaire du COVID-19. https://www.mfa.gouv.qc.ca/fr/publication/Documents/DocumentProtocole_22-mars-2020.pdf

Association québécoise des CPE. (2020b, May 6). Guide des bonnes pratiques Pour lorganisation des services de garde éducatifs en CPE pendant la mesure d'urgence sanitaire du COVID-19. http://www.aqcpe.com/content/uploads/2020/05/guide cpe reouverture covid-19 6-mai final.pdf

Bezanson, K., Bevan, A., Lysack, M., \& Hammer, K. (2020). From stabilization to stimulus and beyond: A roadmap to social and economic recovery. First policy response, April 15, 2020. http://dx.doi.org/10.2139/ssrn.3580746

Blum, S., \& Dobrotić, I. (2020). Childcare-policy responses in the COVID-19 pandemic: Unpacking cross-country variation. European Societies, S545-S563. https://doi.org/10.1080/14616696.2020.1831572

Boast, A., Munro, A., \& Goldstein, H. (2020). An evidence summary of paediatric COVID-19 literature. Don't Forget the Bubbles. https:// doi.org/10.31440/DFTB.24063

Bossé, O. (2020, September 15). Une deuxième vague de COVID-19 trois fois pire? Le Soleil. https://www.ledroit.com/actualites/covid-19/ une-deuxieme-vague-de-covid-19-trois-fois-pire-aa60082790506c81bee9db0ea36fa578

Carli, L. K. (2020). Women, gender equality, and COVID-19. Gender in Management, 35(7-8), 647-655. https://doi.org/10.1108/GM07-2020-0236

Childcare Resource and Research Unit (CRRU). (2020). Re-opening child care centres during COVID-19. https://childcarecanada. org/sites/default/files/Provincial-Territorial-Re-opening\%20guidelines $\% 20$ for $\% 20$ child $\% 20$ care $\% 20$ centres $\% 20 \mathrm{during} \% 20$ COVID Nov\%2018.pdf

Cloutier, E. (2020, November 16). Des pédiatres inquiets pour les ‘bébés COVID. Le Journal de Québec. https://www.journaldequebec. com/2020/11/16/le-masque-nefaste-pour-les-petits

Collins, C., Landicar, C. L., Ruppanner, L., \& Scarborough W. J. (2020). COVID-19 and the gender gap in work hours. Gender, Work and Organization. https://doi.org/10.1111/gwao.12506

Conseil supérieur de l'éducation. (2020). Le bienêtre de l'enfant à l'école: faisons nos devoirs. https://www.cse.gouv.qc.ca/wp-content/ uploads/2020/06/50-0524-AV-bien-etre-enfant-4.pdf

Dion-Viens, D. (2020, March 28). Services de garde d'urgence: Comme une claque en plein visage. Le Journal de Québec. https://www. journaldequebec.com/2020/03/28/comme-une-claque-en-plein-visage

Famille Québec. (2020a). Places existantes et en cours de réalisation dans les services de garde éducatifs à l'enfance reconnus. https:// www.mfa.gouv.qc.ca/fr/services-de-garde/portrait/places/Pages/index.aspx

Famille Québec. (2020b). Summary of plan to gradually reopen childcare services in Québec. http://www.aqcpe.com/content/ uploads/2020/05/resume-plan-reprise-27avril-v7 ang final-v3.pdf

Fortin, P., Godbout, L., \& St-Cerny, S. (2013). Limpact des services de garde à contribution réduite du Québec sur le taux d’activité féminin, le revenu intérieur et les budgets gouvernementaux. Interventions Économiques, 47(1), 1-28. https://doi.org/10.4000/ interventionseconomiques. 1858

Friendly, M., Ballantyne, M., \& Anderson, L. (2020). Rebuilding childcare in Canada must include a national strategy. Policy Options. https://policyoptions.irpp.org/magazines/july-2020/rebuilding-childcare-in-canada-must-include-a-national-strategy/ 
Friendly, M., Feltham, L. E., Mohamed, S., Nguyen, N. T., Vickerson, R., \& Forer, B. (2020a). Early childhood education and care in Canada 2019. Childcare Resource and Research Unit. https://childcarecanada.org/publications/ecec-canada/20/12/early-childhoodeducation-and-care-canada-2019

Friendly, M., Forer, B., Vickerson, R., \& Mohamed, S. (2020b). Canadian child care: Preliminary results from a national survey during the COVID-19 pandemic. Childcare Resource and Research Unit, Child Care Now, \& Canadian Child Care Federation. https:// childcarecanada.org/publications/other-publications/20/07/canadian-child-care-preliminary-results-national-survey-during

Godbout, L., \& St-Cerny, S. (2008). Le Québec, un paradis pour les familles? Regards sur la famille et la fiscalité. Les Presses de l'Université Laval.

Government of Canada. (2020, November 20). Address by the deputy prime minister and minister of finance on the fall economic statement: Supporting Canadians and fighting COVID-19. https://www.canada.ca/en/department-finance/news/2020/11/ supporting-canadians-and-fighting-covid-19.html

Japel, C., \& Friendly, M. (2018). Inequalities in access to early childhood education and care in Canada: The Equal Access Study expert report. ICEC Working Paper Series. https://www.dji.de/fileadmin/user upload/icec/Expertisen/WEB DII Report Canada.pdf

Japel, C., Tremblay, R. E., \& Côté, S. (2005). La qualité, ça compte! Résultats de létude longitudinale du développement des enfants du Québec concernant la qualité des services de garde. Choix IRPP, 11(4). https://on-irpp.org/2Llpkwv

Jenson, J. (2002). Against the current: Child care and family policy in Québec. In S. Michel \& R. Mahon (Eds), Child care policy at the crossroads: Gender and welfare state restructuring (pp. 309-332). Routledge.

Jenson, J., \& St-Marin, D. (2003). New routes to social cohesion? Citizenship and the social investment state. The Canadian Journal of Sociology, 28(1), 77-99.

Mathieu, S. (2019). La transformation de l'offre de services de garde au Québec: Une brèche dans la collectivisation du travail de reproduction sociale? Revue canadienne de sociologie, 56(2), 145-291. https://onlinelibrary.wiley.com/doi/full/10.1111/cars.12243

Mathieu, S., Doucet, A., \& McKay, L. (2020). Parental benefits and inter-provincial differences: The case of four Canadian provinces. Canadian Journal of Sociology, 45(2), 169-194. https://journals.library.ualberta.ca/cjs/index.php/CJS/article/view/29504

Mathieu, S., \& Tremblay, D. G. (2021). L’effet paradoxal de la pandémie sur l'articulation emploi-famille: Le cas du Québec. Revue interventions économiques, 66. https://journals.openedition.org/interventionseconomiques/14234

Ministère de la famille. (2019). Plan stratégique 2019-2023. https://performance.gouv.qc.ca/fileadmin/documents/PS/MFA PS 20192023 VF.pdf

Ministère de la famille. (2020). Accessibilité aux services de garde éducatifs à lenfance: Audit de performance et observations du commissaire au développement durable. Rapport du vérificateur général du Québec à l'assemblée nationale pour l'année 2020-2021. https:// www.vgq.qc.ca/Fichiers/Publications/rapport-annuel/165/vgq ch02 cpe web.pdf

Ministry of Families. (2020). COVID-19 action plan in the event of a second wave: Education childcare services, family community organizations, community drop-in daycare services, and community social pediatrics centres. https://cdn-contenu.quebec.ca/ cdn-contenu/adm/min/education/publications-adm/covid-19/092A-action-plan-wave.pdf?1603483856

Observatoire des tout-petits. (2018). Petite enfance: La qualité de services éducatifs au Québec. https://tout-petits.org/publications/ dossiers/qualite-services-educatifs/

OECD. (2020). Women at the core of the fight against COVID-19 crisis. https://www.oecd.org/coronavirus/policy-responses/women-atthe-core-of-the-fight-against-covid-19-crisis-553a8269/\#contactinfo-d7e4664

Ouellette-Vézina, H. (2021, August 5). Québec recevra 6 milliards sur 5 ans d'Ottawa. La Presse. https://www.lapresse.ca/actualites/ education/2021-08-05/garderies/quebec-recevra-6-milliards-sur-cinq-ans-d-ottawa.php

Prentice, S. (2009). High stakes: The investable child and the economic reframing of childcare. Signs, 34(3), 687-710. 
Prentice, S. (2020). Manitoba child care during COVID-19. In A. Rounce \& K. Levasseur (Eds), COVID-19 in Manitoba: Public policy responses to the first wave (pp. 135-140). University of Manitoba Press.

Rivard, P. (2020, November 10). Québec vise les mauvaises cibles pour contrer la COVID-19. Le Devoir. https://www.ledevoir.com/ opinion/libre-opinion/589435/quebec-vise-les-mauvaises-cibles-pour-contrer-la-covid

Robillard, J.-P. (2020, June 9). Des camps pédagogiques organisés en quelques jours pour des élèves en difficultés. Radio-Canada. https:// ici.radio-canada.ca/nouvelle/1710336/camps-pedagogiques-difficultes-apprentissages-quebec

Samson, F. (2021, January 16). Des travailleuses essentielles confinées à la maison faute de places en garderie. Radio-Canada. https://ici. radio-canada.ca/nouvelle/1762374/garderies-quebec-cpe-places-travailleurs-essentiels-covid

Schué, R. (2019, June 6). Chères, mais convoitées, les garderies non subventionnées plaident la cause des parents. Radio-Canada. https:// ici.radio-canada.ca/nouvelle/1173660/garderies-privees-quebec-cpe-palces-aide-parents-ministre-famille-lacombe

Statistics Canada. (2020). Table 14-10-0018-01: Labour force characteristics by sex and detailed age group, annual, inactive (x 1,000). https://www150.statcan.gc.ca/t1/tbl1/en/tv.action?pid=1410001801

Tougas, J. (2002). Reforming Québec's early childhood care and education: The first five years. Childcare Resource and Research Unit. https://childcarecanada.org/sites/default/files/op17ENG.pdf

Turgeon, L. (2014). Grandeur et misère du système québécois de services de garde à l'enfance [Blog post]. Grandeur et misère du système québécois de services de garde à l'enfance | In Due Course

White, L. (2017). Constructing policy change: Early education and care in liberal welfare states. University of Toronto Press.

Yerkes, M. A., Besamusca, J. W. M., Kruyen, P., Remery, C. L. H. S., van der Zwan, R., Beckers, D. G. J., \& Geurts, S. A. E. (2020). Intelligent lockdown, intelligent effects? The impact of the Dutch COVID-19 'intelligent lockdown' on gendered work and family dynamics among parents. PLOS ONE. https://doi.org/10.1371/journal.pone.0242249

Zossou, C. (2021) Sharing household tasks: Teaming up during the COVID-19 pandemic. Statistics Canada. https://www150.statcan.gc.ca/ n1/pub/45-28-0001/2020001/article/00081-eng.htm 